DOI No: http://dx.doi.org/10.29228/Joh29267

Makale Türü: Araştırma makalesi

Geliş Tarihi: 02.08.2019

Kabul Tarihi: 22.04.2020

On-line Yayın: 30.04.2020
Article Type: Research article

Submitted: 02.08 .2019

Accepted: 22.04 .2020

Published Online: 30.04.2020

Atıf Bilgisi / Reference Information

Üzüm, B. \& Çoban, A. (2020). Mapping English Teachers' Favorable and Unfavorable Behaviors as Voiced by High School Students. Journal of History School, 45, 987-1010.

\title{
MAPPING ENGLISH TEACHERS' FAVORABLE AND UNFAVORABLE BEHAVIORS AS VOICED BY HIGH SCHOOL STUDENTS ${ }^{1}$
}

\author{
Burhan ÜZÜM $M^{2} \&$ Ahmet ÇOBAN ${ }^{3}$
}

\begin{abstract}
This paper aims to examine English teachers' favorable and unfavorable behaviors from viewpoint of high school students, and high school students' opinions about English lesson. The study was carried out with 368 students from different high schools in Siirt. 177 of the students were female and the rest 191 students were males, and students from the four grades participated in the study. In this study, which was carried out with qualitative data collection technique, students' written opinions were elicited through a structured interview form consisting of 3 questions. Content analysis procedures were applied in order to scrutinize the data. According to the study results, among favorable teachers' behaviors, the first three ones ranked as follows being caring/ understanding/tolerant, being able to teach well and entertaining/humorous. On the other hand, among unfavorable teachers' behaviors, the first three ones were found to be harsh, indifferent/insensitive/intolerant and not teaching effectively. Regarding teaching profession competence areas, favorable behaviors of English teachers in the present study mostly fell into the professional skill area whereas most of the unfavorable behaviors were in the attitude and value competence area. As to the students' views about English

1 Makale yazımı yazar etki oranı: 1.yazar \%50 2.yazar \%50

${ }^{2}$ Öğr. Gör., Siirt Üniversitesi, Yabancı Diller ve Kültürler, Uygulamalı İngilizce ve Çevirmenlik Bölümü, uzum_b@siirt.edu.tr Orcid: 0000-0003-3385-5841

${ }^{3}$ Doç. Dr., Dicle Üniversitesi, Ziya Gökalp Eğitim Fakültesi, Eğitim Bilimleri Bölümü, Eğitim Programları ve Öğretim Anabilim Dalı, ahcoban@gmail.com Orcid: 0000-0002-8177-5670
\end{abstract}




\section{Burhan ÜZÜM \& Ahmet ÇOBAN}

lesson, it was investigated that female students had more positive opinions towards the English lesson than male students did.

Keywords: Qualitative method, English teacher, Students' view, Behavior, English lesson

\section{Lise Öğrencilerinin Sesinden İngilizce Öğretmenlerinin Olumlu ve Olumsuz Davranıșları}

$\ddot{O} \mathbf{z}$

$\mathrm{Bu}$ çalışma, lise öğrencilerinin görüşlerine göre, İngilizce öğretmenlerinin olumlu ve olumsuz davranışları ile öğrencilerin İngilizce dersine dair görüşlerini incelemyi amaçlamaktadır. Çalışma Siirt ilinde bulunan farklı liselerden 368 öğrenci ile gerçekleştirilmiştir. Katılımcıların 177'si kız geriye kalan 191'i erkek olup her sınıf seviyesinden öğrenci katılmıştır. Çalışma grubunun belirlenmesinde amaçlı örnekleme yöntemlerinden ölçüt örnekleme tekniği kullanılmıştır. Nitel veri toplama tekniği ile gerçekleşen bu çalışmada toplam 3 sorudan oluşan yapılandırılmış görüşme formu aracılığıyla öğrencilerden yazılı görüş alınmıştır. Veriler, içerik analizi prosedürüne göre çözümlenmiştir. Araştırma sonuçlarına göre, İngilizce öğretmenlerinin öğrencilere karşı olumlu davranışları arasında ise ilk üç sırada ilgili-anlayışlı olmaları, dersi iyi anlatmaları ve esprili-eğlenceli olmaları olduğu ortaya çıkmıştır. Diğer taraftan İngilizce öğretmenlerinin öğrencilere karşı olumsuz davranışları arasında ilk üç sırada öğrenciye karşı sert ve ilgisiz olma, etkili öğretememe olduğu tespit edilmiştir. Öğretmenlik mesleği yeterlik alanlarında ise olumlu davranışların çoğunluğu mesleki beceri alanına denk gelirken olumsuz davranışların çoğu değer ve tutum alanına düşmüştür. Öğrencilerin İngilizce dersi ile ilgili görüşlerine göre, kız öğrencilerin İngilizce dersine karşı erkek öğrencilere göre daha olumlu görüşlere sahip olduğu incelenmiştir.

Anahtar Kelimeler: Nitel yöntem, İngilizce öğretmeni, Öğrenci görüşü, Davranış, İngilizce dersi

\section{INTRODUCTION}

Occupational adequacy of teachers alone is not enough for an efficient and effective teaching and learning process. As well as occupational adequacy, teachers' attitudes, behaviours and approaches towards students are important factors in successfully handling this process. Şişman (2004) states that such agents as teachers, curriculum, managers, pyhsical and financial sources have important effects on students' achievement and attitudes towards the lesson in the teaching-learning process (as cited in Demirtaş, Cömert and Özer, 2011, p. 98).

With his attitudes and behaviours, teacher is an important agent in students' learning environment. Most of the time, this 'agent' is in the center of this 
Mapping English teachers' favorable and unfavorable behaviors as voiced by high school students

process. When there is a need for direct relation between the teacher and the student, the attitudes and behaviours of the teachers form an important part of conditions necessary for learning (Ashton and Webb, 1986, cited in Gurbetoğlu and Tomakin, 2011, p. 62; Ertürk, 2013). In order for the student to develop positive attitudes towards the lesson and like the teacher and the course, the teacher should have a rapport and behave in such a way that could motivate student.

Rather than having such strict disciplinary manners as punitive, threatening, tyrnnical, the teacher, one of the key players in teaching activities, is supposed to have a motivating approach in which he cares individual differences, interests and needs of students and their affective characteristics. Building good relationships with students, being vigorous, cheerful and happy are among good qualities of an influential teacher (Reed and Bergeman, 1992 as cited in Gurbetoğlu and Tomakin, 2011, p. 263). It is well-known that teachers who are sincere and patient with their students have positive effects on students while the opposite behaviours of teachers have an adverse affect on both students and classroom management (Sanford and Emmer, 1988; Ergün and Duman, 2000; Güçlü, 2002; Jeans, 1995 as cited in Şahin, 2011, p. 241).

Teachers' manners towards students either decrease or increase foreign language anxiety. In their study 'Anxiety In Foreign Language Teaching: A Literature Review", Aydın and Zengin (2008, pp. 82-94) determined anxiety causing factors like efficacy level of students, examinations, difficulty level of language courses and cultural differences as well as teachers' behaviours. As cited in Ergür (2004, p. 51), Rardin, Tranel, Tirone and Green (1988) also emphasized the importance of teachers' being good listeners and developing a sense of empathy for their students. The information stated up to this point makes it clear that teachers have a variety of competencies, skills and knowledge. In this context, the Ministry of the National Education (MoNE) launched a revised framework for "General Competencies in Teaching Profession". According this framework, these competence areas consist of three main areas and are as follows: "professional knowledge", professional skills" and "attitudes and values". Each of these competence areas has 11 sub-competencies and there are 65 indicators in total related to these areas (MoNE, 2017). Since they are among key indicators of students' academic achievement and of their views about the lesson, it is thought that analyzing teachers' behaviours in our educational system is important. In the light of thoughts presented above, this paper aims to examine English teachers' favorable and unfavorable behaviors from the viewpoint of high school students, and their opinions about English lesson. 


\section{Burhan ÜZÜM \& Ahmet ÇOBAN}

\section{Research Objectives}

The purpose of this study was to analyze attitudes of English teachers towards students at high school and determine students' views about English lesson. Thus, the following research questions were determined to be answered:

1. What are the positive and negative opinions of students about English teachers?

2. How is the distribution of the positive and negative opinions of students about English teachers in terms of "teaching profession competence areas"?

3. How is the distribution of the positive and negative opinions of students about English teachers in terms of their gender?

4. How is the distribution of the positive and negative opinions of students about English teachers in terms of their grade level?

5. What are the students' opinions towards English lesson and the reasons lying behind these opinions?

\section{Research Importance}

Reviewing the literature, it was seen that the attitudes and behaviours in th teaching-learning process were searched according to different variables and from different viewpoints. The studies carried out on this topic can be divided into three categories a) teachers' point of view b) students' point of view c) both teachers' and students' point of views. The studies taking teachers' viewpoints into account (Büyükkaragöz and Kesici, 1996; Büyüköztürk, et al. 2004; Semerci and Semerci, 2004; Walker, Shafer and liams, 2004; Sarıtaş, 2006; Deniz, Avşaroğlu and Fidan, 2006; Lavrič, 2006; Reeves, 2006; Bozdoğan, Aydın and Y1ldırım, 2007; Balay and Sağlam, 2008; Bulut, 2009; Ahmad and Sahak, 2009; Siyez, 2009; Smith, 2010; Şahin, 2011; Demirtaş, Cömert and Özer, 2011; Koutrouba, 2013; Sun and Shek, 2012; Konur and Konur, 2014) are generally about attitudes and behaviors of students from teachers' viewpoints, and attitudes of teachers towards teaching profession. The studies based solely on students' viewpoints (Gorham and Christopel, 1992; Ergin and Geçer, 1999; Çapa and Çil, 2000; Senemoğlu, 2001; Öztürk, Koç and Şahin, 2002; Geçer and Deryakulu, 2004; Batumlu and Erden, 2007; Kumral, 2009; Gurbetoğlu and Tomakin, 2011; Huan et al. 2012; Mehdipour and Balaramulu, 2013) analyze attitudes of teachers towards students. The studies on attitudes and behaviors in the learning environment according to the students' opinions (Ergün and Duman, 2000; Altinel, 2006; Sert, 2007; Vural, 2007; Celebi, 2009; Atici and Cekici, 2009; 
Mapping English teachers' favorable and unfavorable behaviors as voiced by high school students

Şahin and Arslan, 2014; Tuncel and Balci, 2015), on the other hand, were found to be limited in number and rather than being for a certain branch. They were only an evaluation in a general sense. As stated above, some of the studies up to now (Altınel, 2006; Çelebi, 2009; Huan at al. 2012) included the opinions of the teachers and students at primary or secondary education level, and some of them (Semerci and Semerci, 2004; Gurbetoğlu and Tomakin, 2011; Mehdipour and Balaramulu, 2013) were conducted to university students. The present study is thought to be important both in terms of exploring the favorable and unfavorable behaviors of English teachers from the point of view of high school students and the effect of these behaviors on the opinions of the students about the English lesson.

\section{METHODOLOGY}

This chapter includes information on research desing, study group, data collection tools and data analysis.

\section{Research Design}

Qualitative research method was used in the present study. Qualitative research is "a research that uses qualitative data gathering methods such as observation, interview and document analysis, and a qualitative process in which the perceptions and events are revealed in a natural and realistic manner" (Yıldırım and Şimşek, 2013, p. 45). Case study, one of the qualitative research desings, was used for the present study. According to Creswell (2016, p.97), case study is a qualitative approach in which the researcher has the opportunity to analyze events in detail and in depth through various and multiple sources of information such as observation, interview, documents and reports. In the present study, the data neeeded was collected through structured interview forms.

\section{Study Group}

Taking into account thay they had taken English classes since primary school, high school students were determined as the study group of the present study because they had more experience with English teachers. Therefore, in the present study, the universe was the students at the secondary education institutions located in the city center of Siirt, in spring term of 2015-2016 academic year. The criterion sampling technique, one of the purposive sampling methods, was used in determining the sample of the study. Depending on the objectives of the study, purposive sampling allows in-depth research by selecting cases rich in information. Criterion sampling is the creation of samples, events, 
objects, or situations that have qualities relevant to the problem (Büyüköztürk, Çakmak, Akgün, Karadeniz and Demirel, 2016, pp. 90-92). Here the basic criterion was high school students. Becasuse high school students are exposed to English lesson approximately 6 years until they enrol at high school. They are thought to have observed English teachers' behaviors more than any other students during these years. So, it can be said that they have more in depth information about their English teachers' behaviors. No one, other than these high school students, can best describe English teachers' favorable and unfavorable behaviors. As a result, the study was conducted to the students at the four Anatolian High Schools (Atatürk Anatolian High School, Selami Değer Anatolian High School, Siirt Anatolian Imam Hatip High School, Zübeyde Hanım Vocational and Technical Anatolian High School). The informaiton about the students in the sample is provided in Table 1 below.

Table 1

Information About Participants in the Interview

\begin{tabular}{clcc}
\hline Variables & & f & \% \\
\hline \multirow{3}{*}{ Gender } & Female & 177 & 48 \\
& Male & 191 & 52 \\
& Total & $\mathbf{3 6 8}$ & $\mathbf{1 0 0}$ \\
\hline \multirow{4}{*}{ Grade } & 9 & 181 & 49 \\
& 10 & 84 & 23 \\
& 11 & 92 & 25 \\
& 12 & 11 & 3 \\
\cline { 2 - 4 } & Total & $\mathbf{3 6 8}$ & $\mathbf{1 0 0}$ \\
\hline
\end{tabular}

Table 1 shows that the majority of the students participated in the study consisted of $9^{\text {th }}$ grade students with a rate of $49 \%$, and the participation of the $10^{\text {th }}$ and $11^{\text {th }}$ grades was nearly equal with the rates $23 \%$ and $25 \%$, and the $12^{\text {th }}$ grades had the lowest participation with a rate of $3 \%$. As regards the gender, it was determined that the number of the males and female participants was found to be close to each other. The number of the females was $177(48 \%)$ and the number of the males was $191(52 \%)$.

The reason why the number of the $12^{\text {th }}$ grades was so small in the sample is assumed to be due to the fact that they were studying Higher Education Transition Examination (HETE) and they were at their last grade. Since such a small number of students could not represent $12^{\text {th }}$ grade, the opinions obtained from this group of students were not included in the data analysis. 
Mapping English teachers' favorable and unfavorable behaviors as voiced by high school students

\section{Data Collection Tools}

In the present study, structured interview forms were used as data collection tool. There are a series of questions prepared in an order by the researcher in advance in the structured interview forms. This method enables the data to be quickly coded, analyzed and measured (Buyukozturk et al. 2016, p. 154).

Students were asked to take into account the English teachers who had attended their lessons so far and a total of three questions were included in the interview forms in order to determine (1) unfavorable teacher behaviors, (2) favorable teacher behaviors, and (3) students' opinions on English lessons. To check how well the developed forms served the objectives of the study, their clarity and applicability, experts in the fields of education curriculums and teaching $(n=3)$, in Eglish teaching $(n=2)$ and English teachers $(n=5)$ were consulted. Field experts and teachers suggested that interview forms were appropriate, clear and feasible. The questions in the interview form were as follows:

1. Write down the 3 favorable behaviors of the English teachers who have entered your course so far.

2. Write down the 3 unfavorable behaviors of the English teachers who have entered your course so far.

3. What do you think about the English lesson? Why? Why not?

\section{Data Analysis}

As a result of the data analysis of the interviews, following findings were obtained:

- Those who wrote 2 unfavorable behaviors and din not write1,108 (\%29)

- Those who wrote 1 unfavorable behaviors and din not write 2, 57 (\%15)

- Those who did not write any unfavorable behaviors, 55 (\%15). Analysis of the unfavorable behaviors was made on the remaining 717 behaviors.

As to the posivite behaviors;

- Those who wrote 2 favorable behaviors and din not write 1, 117 (\%32)

- Those who wrote 1 favorable behaviors and din not write 2, 39 (\%11) 


\section{Burhan ÜZÜM \& Ahmet ÇOBAN}

- Those who did not write any favorable behaviors, $45(\% 12)$. Analysis of the favorable behaviors was made on the remaining 774 behaviors.

After the above-mentioned determinations were made, 717 unfavorable and 774 favorable behaviors were divided into categories according to certain characteristics and the frequencies and percentages of the behaviors mentioned in these categories were determined. Category is the classification of the concepts obtained in content analysis under a certain theme in relation to each other (Yıldırım and Şimşek, 2013, p.260). As a result of the analysis, positive behaviors were collected under a total of 15 categories (See Table 2) and the negative behaviors under 17 categories (See Table 3). To strikingly reflect the opinions of the students about English lesson, direct citations from their opinions were provided (Yıldırım and Şimşek, 2013, p. 253). Students were numbered from 1368. Direct quotations from the students' views are written in quotation marks and in italics. Direct citations of students' opinions were coded as FS (Female Student) and MS (Male Student).

\section{RESULTS}

\section{Findings related to the first sub-problem}

a) The findings on the favorable behaviors of English teachers according to the opinions of high school students

The findings on the favorable behaviors of English teachers according to the opinions of high school students and the frequency of the behaviors are shown in Table 2.

Table 2 reveals that among the first four behaviors that students evaluated as positive in English teachers were being understanding and tolerant ranked at the top with a frequency of 168. The other three top behaviours were teaching well ( $\mathrm{f}=129)$, being entertaining and humorous $(\mathrm{f}=124)$ and being cheeerful and loving ( $\mathrm{f}=114)$. According to the opinions of the high school students, the favorable behaviors of English teachers found to be moderately frequent were as follows: being fair $(\mathrm{f}=51)$, presenting activities $(\mathrm{f}=36)$, being encouraging $(\mathrm{f}=33)$ and being helpful $(\mathrm{f}=26)$. On the other hand, the positive behaviors least stated by the students were classroom management, attending class prepared, teaching grammar, teaching in English 
Mapping English teachers' favorable and unfavorable behaviors as voiced by high school students

\section{Table 2}

Favorable Behaviors of English Teachers According to the High School Students' Opinions and Frequency of the Behaviors

\begin{tabular}{lc}
\hline \multicolumn{1}{c}{ FAVORABLE BEHAVIORS } & $\begin{array}{c}\text { Frequency } \\
\text { (f) }\end{array}$ \\
\hline 1.Caring/Understanding/Tolerant & 168 \\
2.Teaching well & 129 \\
3.Entertaining/Humorous & 124 \\
4.Cheerful/Loving & 114 \\
5.Diligent/Endeavouring & 55 \\
6.Fair & 51 \\
7.Presenting activities (speaking, & 36 \\
listening, pronounciationso on) & \\
8.Encouraging & 33 \\
9.Helpful & 26 \\
10.Good classroom management & 14 \\
11.Coming to class prepared & 12 \\
12.Teaching grammar & 4 \\
13.Teaching in English & 4 \\
14.Attending the class on time & 2 \\
15.Speaking Turkish during the lesson & 2 \\
\hline Total & 774 \\
\hline
\end{tabular}

b) Findings on the opinions of the high school students about unfavorable behaviors of English teachers

Unfavorable behaviors of English teachers according to the high school students' opinions and the frequency of the behaviors are given in Table 3.

In Table 3, it is seen that the most frequently stated first four unfavorable behaviors were as follows: English teachers' often shouting at and getting angry with students and thus being harsh towards students ( $\mathrm{f}=120)$, being indifferent/insensitive and intolerant to needs and problems of the students $(\mathrm{f}=104)$, not being able to teach English efficiently $(\mathrm{f}=89)$ and English teachers' discrimination between students $(\mathrm{f}=80)$. In other words, according to the opinions of the high school students, the most first four unfavorable behaviors of Englsih teachers were being harsh and indifferent, not being able to teach English efficiently due to wrong methods (constantly making students memorize words, dictating writing, not practising, not paying attention to daily conversations and 
pronounciation, often having them translate texts) and discriminating between students who were good at English, participated in the activities, didn't like English.

\section{Table 3}

Unfavorable Behaviors of English Teachers According to the High School Students' Opinions and Frequency of the Behaviors

\begin{tabular}{lc}
\hline UNFAVORABLE BEHAVIORS & $\begin{array}{c}\text { Frequency } \\
\text { (f) }\end{array}$ \\
\hline 1.Harsh & 120 \\
2.Indifferent/Insensitive/Intolerant & 104 \\
3.Not teaching efficiently & 89 \\
4.Discrimination & 80 \\
5.Excessive homework & 58 \\
6.Humiliation & 57 \\
7.Low marks & 45 \\
8.Boring teacher and lesson & 45 \\
9.Oppressing & 25 \\
10.Threaten & 19 \\
11.Hard exams & 19 \\
12.Violence & 16 \\
13.Teaching just grammar & 12 \\
14.Dealing with something else & 10 \\
15.Bad classroom management & 8 \\
16.Not speaking English & 7 \\
17.Not attending class on time & 2 \\
18.Not knowing students' names & 1 \\
\hline Total & $\mathbf{7 1 7}$ \\
\hline
\end{tabular}

On the other hand, the unfavorable behaviors which were stated by the students and whose frequency rate were moderate are as follows: giving assignments more than necessary $8 \%$, humiliation (harsh criticism, joke, ridicule, nicknaming, demoralising) $8 \%$, giving low marks $6 \%$, boringness of the lesson and teacher $6 \%$.

The rate of less repetitive unfavorable behaviors, however, are as follows: putting pressure on students $3 \%$, threatening students with marks, parents and administers 3\%, difficult examinations (questions from the parts which haven't been taught, providing exams often based on memorization) $3 \%$, violence (hitting students, throwing chalks and so on) $2 \%$, teaching just grammar $2 \%$, 
Mapping English teachers' favorable and unfavorable behaviors as voiced by high school students

dealing with other things during the lesson, bad classroom management, not speaking English in the class 1\% each, and not attending the classroom on time and not knowing the name of the students ranked last with $0,5 \%$ each.

\section{Findings related to second sub-problem}

a) Findings on the distribution of the favorable opinions of students about the English teachers in terms of "teaching profession competence" areas

The distribution of the favorable opinions of students about the English teachers in terms of "teaching profession competence areas" is presented in Table 4.

\section{Table 4}

The distribution of the favorable opinions of students about the English teachers in terms of "teaching profession competence" areas

\begin{tabular}{|c|c|c|}
\hline \multicolumn{3}{|c|}{ Favorable Behaviors In Terms of Teaching Profession Competence } \\
\hline Prossional Knowledge & Professional Skills & Attitude and Value \\
\hline $\begin{array}{ll}\text { - } & \text { Presenting } \\
\text { activities } \\
\text { - } \\
\text { Speaking } \\
\text { Turkish during } \\
\text { the lesson } \\
\text { Teaching in } \\
\text { English }\end{array}$ & $\begin{array}{ll}\text { - } & \text { Teaching well } \\
\text { - } & \text { Fair } \\
\text { - } & \text { Encouraging } \\
\text { - } & \text { Good } \\
& \text { classroom } \\
& \text { management } \\
\text { - } & \text { Coming to } \\
& \text { class prepared } \\
\text { - } & \text { Teaching } \\
\text { grammar }\end{array}$ & $\begin{array}{ll}\text { - } & \text { Caring/Understanding/Tolerant } \\
\text { - } & \text { Entertaining/Humorous } \\
\text { - } & \text { Cheerful/Loving } \\
\text { - } & \text { Diligent/Endeavouring } \\
\text { - } & \text { Helpful } \\
\text { - } & \text { Attending the class on time }\end{array}$ \\
\hline
\end{tabular}

Table 4 demonstrates that the favorable behaviors of English teachers are more accumulated around professional skills and attitude and value competence areas in terms of teaching profession competence areas. According to the views expressed by the students, 6 favorable behaviors correspond to professional skills and 6 favorable behaviors match up to attitude and value competence areas. On the other hand, it is seen that 3 favorable behaviors are expressed in the field of professional knowledge competence, which is a field of competence including field knowledge, knowledge of field education and knowledge of legislation. 
b) Findings on the distribution of the unfavorable opinions of students about the English teachers in terms of "teaching profession competence"

Findings on the distribution of the unfavorable opinions of students about the English teachers in terms of "teaching profession competence" are presented in Table 5 .

\section{Table 5}

The distribution of the unfavorable opinions of students about the English teachers in terms of "teaching profession competence" areas

\begin{tabular}{|c|c|c|}
\hline \multicolumn{3}{|c|}{ Unfavorable Behaviors In Terms of Teaching Profession Competence } \\
\hline $\begin{array}{c}\text { Professional } \\
\text { Knowledge }\end{array}$ & Professional Skills & Attitude and Value \\
\hline $\begin{array}{ll}\text { - } & \text { Excessive } \\
\text { homework } \\
\text { - } & \text { Teaching just } \\
& \text { grammar } \\
\text { - } & \text { Not } \\
\text { speaking } \\
\text { English }\end{array}$ & $\begin{array}{ll}\text { - } & \text { Not teaching } \\
\text { efficiently } \\
\text { - } & \text { Low marks } \\
\text { - } & \text { Boring } \\
& \text { teacher and } \\
& \text { lesson } \\
\text { - } & \text { Hard exams } \\
\text { - } & \text { Violence } \\
\text { - } & \text { Bad } \\
\text { classroom } \\
\text { management }\end{array}$ & $\begin{array}{ll}\text { - } & \text { Harsh } \\
\text { - } & \text { Indifferent/Insensitive/Intol } \\
& \text { erant } \\
\text { - } & \text { Discrimination } \\
\text { - } & \text { Humiliaton } \\
\text { - } & \text { Oppressing } \\
\text { - } & \text { Threaten } \\
\text { - } & \text { Dealing with something else } \\
\text { - } & \text { Not attending class on time } \\
\text { - } & \text { Not knowing students' } \\
& \text { names }\end{array}$ \\
\hline
\end{tabular}

Table 5 suggests that the majority of unfavorable behaviors expressed by students are in the field of attitude and value competence. In other words, it turns out that attitudes and values covering the competence areas such as approach to and communication with students, which include the general attitudes and values towards the teaching profession, of the unfavorable behavioral types 9 ones correspond to this field of competence. The second area of competence where unfavorable behaviors take the most place is the field of professional skills with 6 unfavorable behaviors. It is seen that the proficiency field in which the least unfavorable behaviors are found is the field of professional knowledge competence with 3 unfavorable behaviors. 
Mapping English teachers' favorable and unfavorable behaviors as voiced by high school students

\section{Findings related to the third sub-problem}

a) Findings on the distribution of the favorable opinions of students about the English teachers in terms of gender

Findings on the distribution of the favorable opinions of students about the English teachers in terms of gender are presented in Table 6.

\section{Table 6}

The distribution of the favorable opinions of students about the English teachers in terms of gender

\begin{tabular}{|c|c|c|c|}
\hline \multirow[t]{3}{*}{ FAVORABLE BEHAVIORS } & \multicolumn{3}{|c|}{ GENDER } \\
\hline & FEMALE & MALE & \\
\hline & $\begin{array}{l}\text { Frequency } \\
\text { (f) }\end{array}$ & $\begin{array}{c}\text { Frequency } \\
\text { (f) }\end{array}$ & Total \\
\hline 1. Caring/Understanding/Tolerant & 78 & 90 & 168 \\
\hline 2. Teaching well & 69 & 60 & 129 \\
\hline 3. Entertaining/Humorous & 66 & 58 & 124 \\
\hline 4. Cheerful/Loving & 48 & 66 & 116 \\
\hline 5. Diligent/Endeavouring & 30 & 25 & 53 \\
\hline 6. Fair & 30 & 19 & 49 \\
\hline $\begin{array}{l}\text { 7.Presenting activities (speaking, } \\
\text { listening, pronounciation so on) }\end{array}$ & 25 & 8 & 33 \\
\hline 8. Encouraging & 7 & 25 & 32 \\
\hline 9. Helpful & 13 & 10 & 23 \\
\hline 10. Good classroom management & 7 & 11 & 14 \\
\hline 11. Coming to class prepared & 6 & 7 & 10 \\
\hline 12. Teaching grammar & 3 & 3 & 4 \\
\hline 13. Teaching in English & 3 & 3 & 4 \\
\hline 14. Attending the class on time & 0 & 2 & 2 \\
\hline $\begin{array}{l}\text { 15. Speaking Turkish during the } \\
\text { lesson }\end{array}$ & 0 & 2 & 2 \\
\hline Total & 385 & 389 & 774 \\
\hline
\end{tabular}

When the distribution of favorable behaviors in terms of gender is examined in Table 6, it is seen that total frequencies [Female $(f=385)$, Male $(f$ = 389)] are very close to each other. An in depth examination of favorable behaviors one by one reveals that the frequencies of other behaviors are close to each other except for caring/understanding/tolerant, cheerful/loving, fair and 
encouraging behaviors. It is seen that while caring/understanding/tolerant, cheerful/loving and encouraging behaviors are more expressed among the males than the girls, fair and presenting activities behaviors are expressed more by the girls. Besides, it turns out that the two behaviors (attending the class on time and speaking Turkish during the lesson ) are only expressed by males.

\section{b) Findings on the distribution of the unfavorable opinions of students about the English teachers in terms of gender}

Findings on the distribution of the unfavorable opinions of students about the English teachers in terms of gender are presented in Table 7.

\section{Table 7}

The distribution of the unfavorable opinions of students about the English teachers in terms of gender

\begin{tabular}{lccc}
\hline UNFAVORABLE BEHAVIORS & \multicolumn{3}{c}{ GENDER } \\
\hline & FEMALE & MALE & \multirow{2}{*}{ Total } \\
\cline { 2 - 4 } 1.Harsh & Frequency (f) & Frequency (f) & 120 \\
\cline { 2 - 3 } 2. Indifferent/Insensitive/Intolerant & 59 & 66 & 104 \\
3. Not teaching efficiently & 54 & 45 & 89 \\
4. Discrimination & 59 & 35 & 80 \\
5. Excessive homework & 13 & 21 & 58 \\
6. Humiliation & 27 & 45 & 57 \\
7. Low marks & 19 & 30 & 45 \\
8. Boring teacher and lesson & 21 & 26 & 45 \\
9. Oppressing & 12 & 24 & 25 \\
10. Threaten & 6 & 13 & 19 \\
11. Hard exams & 2 & 13 & 19 \\
12. Violence & 4 & 17 & 16 \\
13. Teaching just grammar & 8 & 12 & 12 \\
14. Dealing with something else & 3 & 4 & 10 \\
15. Bad classroom management & 2 & 7 & 8 \\
16. Not speaking English & 2 & 6 & 7 \\
17. Not attending class on time & 2 & 5 & 2 \\
18.Not knowing students' names & 1 & 0 & 1 \\
\hline Total & $\mathbf{3 4 8}$ & 0 & $\mathbf{3 6 9}$ \\
\hline
\end{tabular}


Mapping English teachers' favorable and unfavorable behaviors as voiced by high school students

When the distribution of unfavorable behaviors in terms of gender is examined in Table 7, it is seen that male students declare 21 more unfavorable behaviors than female students [Female $(f=348)$, Male $(f=369)$ ]. It is investigated that the frequencies of the 9 unfavorable behaviors (humiliation, boring teacher and lesson, oppressing, teaching just grammar, dealing with something else, bas classroom management, not speaking English, not attending class on time and not knowing students' names) are very close to each other. However, there are obvious differences in the frequency of expression among girls and boys in the remaining 9 behaviors (harsh, indifferent/insensitive/intolerant, not teaching efficiently, discrimination, excessive homework, low marks, threaten, hard exams and violence). It turns out that being harsh, excessive homework, low marks, threaten, hard exams and threaten behaviors were voiced by males while being indifferent/insensitive/intolerant, not teaching efficiently and discrimination behaviors were expressed more by females. Apart from this, it is seen that the two behaviors (not attending class on time and not knowing the students' names) were never expressed by males.

\section{Findings related to the fourth sub-problem}

a) Findings on the distribution of the favorable opinions of students about the English teachers in terms of grade level

Findings on the distribution of the favorable opinions of students about the English teachers in terms of grade level are presented in Table 8.

Looking at the distribution of favorable behaviors according to grade level, it is seen that $9^{\text {th }}$ graders expressed the most favorable behaviors with 369 frequencies. It is revealed that the $11^{\text {th }}$ grade is $2^{\text {nd }}$ with 209 frequencies and the $10^{\text {th }}$ grade $3^{\text {rd }}$ with 196 frequencies. In all favorable behavior dimensions, it is seen that the $9^{\text {th }}$ grade has the highest frequencies and the $10^{\text {th }}$ and $11^{\text {th }}$ grade have close frequencies. 


\section{Table 8}

The distribution of the favorable opinions of students about the English teachers in terms of grade level

\begin{tabular}{lcccc}
\hline \multicolumn{1}{c}{ FAVORABLE BEHAVIORS } & \multicolumn{4}{c}{ GRADES } \\
\cline { 2 - 4 } & $\begin{array}{c}\mathbf{9} \\
\text { Frequency } \\
\text { (f) }\end{array}$ & $\begin{array}{c}\text { Frequency } \\
\text { (f) }\end{array}$ & $\begin{array}{c}\text { Frequency } \\
\text { (f) }\end{array}$ & Total \\
\cline { 2 - 4 } & 74 & 49 & 45 & 168 \\
1. Caring/Understanding/Tolerant & 68 & 37 & 24 & 129 \\
2. Teaching well & 49 & 37 & 38 & 124 \\
3. Entertaining/Humorous & 64 & 27 & 25 & 116 \\
4. Cheerful/Loving & 20 & 12 & 18 & 53 \\
5. Diligent/Endeavouring & 32 & 5 & 12 & 49 \\
6. Fair & 12 & 9 & 12 & 33 \\
7.Presenting activities (speaking, & & & & \\
listening, pronounciation so on) & 19 & 4 & 9 & 32 \\
8. Encouraging & 13 & 5 & 5 & 23 \\
9 Helpful & 10 & 2 & 2 & 14 \\
10. Good classroom management & 7 & 3 & 0 & 10 \\
11. Coming to class prepared & 0 & 1 & 3 & 4 \\
12. Teaching grammar & 1 & 0 & 3 & 4 \\
13. Teaching in English & 0 & 2 & 0 & 2 \\
14. Attending the class on time & 0 & 0 & 2 & 2 \\
15. Speaking Turkish during the & & & & \\
lesson & $\mathbf{3 6 9}$ & $\mathbf{1 9 6}$ & $\mathbf{2 0 9}$ & $\mathbf{7 7 4}$ \\
\hline \multicolumn{2}{c}{ Total } & & &
\end{tabular}

Findings on the distribution of the unfavorable opinions of students about the English teachers in terms of grade level

Findings on the distribution of the unfavorable opinions of students about the English teachers in terms of grade level are presented in Table 9. 
Mapping English teachers' favorable and unfavorable behaviors as voiced by high school students

\section{Table 9}

The distribution of the unfavorable opinions of students about the English teachers in terms of grade level

\begin{tabular}{lcccc}
\hline UNFAVORABLE BEHAVIORS & \multicolumn{4}{c}{ GRADES } \\
\cline { 2 - 4 } & $\mathbf{9}$ & $\mathbf{1 0}$ & $\mathbf{1 1}$ & \\
\cline { 2 - 4 } & $\begin{array}{c}\text { Frequency } \\
\text { (f) }\end{array}$ & $\begin{array}{c}\text { Frequency } \\
\text { (f) }\end{array}$ & $\begin{array}{c}\text { Frequency } \\
\text { (f) }\end{array}$ & Total \\
\cline { 2 - 4 } Harsh & 73 & 20 & 27 & 120 \\
2. Indifferent/Insensitive/Intolerant & 43 & 26 & 35 & 104 \\
3. Not teaching efficiently & 32 & 30 & 27 & 89 \\
4. Discrimination & 36 & 30 & 14 & 80 \\
5. Excessive homework & 46 & 8 & 4 & 58 \\
6. Humiliation & 15 & 13 & 29 & 57 \\
7. Low marks & 24 & 14 & 7 & 45 \\
8. Boring teacher and lesson & 15 & 21 & 9 & 45 \\
9. Oppressing & 7 & 5 & 13 & 25 \\
10. Threaten & 6 & 0 & 13 & 19 \\
11. Hard exams & 7 & 6 & 6 & 19 \\
12. Violence & 12 & 2 & 2 & 16 \\
13. Teaching just grammar & 1 & 1 & 10 & 12 \\
14. Dealing with something else & 5 & 0 & 5 & 10 \\
15. Bad classroom management & 5 & 0 & 3 & 8 \\
16. Not speaking English & 1 & 0 & 6 & 7 \\
17. Not attending class on time & 1 & 0 & 1 & 2 \\
18. Not knowing students' names & 0 & 1 & 0 & 1 \\
\hline Total & $\mathbf{3 2 9}$ & $\mathbf{1 7 7}$ & $\mathbf{2 1 1}$ & $\mathbf{7 1 7}$ \\
\hline
\end{tabular}

Table 9, which shows the distribution of the unfavorable behaviors in terms of grade level, indicates that the $10^{\text {th }}$ and $11^{\text {th }}$ graders have the closest frequencies and $9^{\text {th }}$ graders the highest frequencies. In other words, the $10^{\text {th }}$ graders $3^{\text {rd }}$ with 177 frequencies, and $11^{\text {th }}$ graders $2^{\text {nd }}$ with 211 frequencies, the $9^{\text {th }}$ grades ranked $1^{\text {st }}$ with 325 frequencies. It is seen that the 9 th graders have the highest frequency in all behavioral dimensions except humiliation, boring teacher and lesson, oppressing, threaten, teaching just grammar and not speaking English behavioral dimensions. In these behavioral dimesions, except for boring teacher and lesson, $11^{\text {th }}$ graders have more frequency than the other grades. 


\section{Burhan ÜZÜM \& Ahmet ÇOBAN}

\section{Findings related to the fifth sub-problem}

The positive and negative opinions of high school students about the English lesson are shown in Table 10.

\section{Table 10}

High School Students' Opinions about English Lesson and Frequency of the Opinions

\begin{tabular}{|c|c|c|c|c|c|c|}
\hline \multirow{2}{*}{ Variables } & & \multicolumn{5}{|c|}{ Students' Opinions About English Lesson } \\
\hline & & Positive & Opinions & Negativ & Opinions & Total \\
\hline \multirow{2}{*}{ Gender } & Female & 133 & $\% 75$ & 44 & $\% 25$ & $\begin{array}{c}177 \\
0.1 \mathrm{nn}\end{array}$ \\
\hline & Male & 97 & $\% 51$ & 94 & $\% 49$ & $\begin{array}{c}191 \\
\text { or1nn }\end{array}$ \\
\hline Total & & 230 & $\% 63$ & 138 & $\% 37$ & 368 \\
\hline
\end{tabular}

Table 10 points out that female students' opinions about English lessons $(58 \%)$ are higher than their negative opinions $(42 \%)$. Compared to male students, female students (58\%) seem to have a more positive view of English lessons. It is seen that the positive (97) and negative (94) views of male students towards English lessons are almost equal. In other words, almost half of the male students have negative views towards English lessons, while the other half has positive opinions.

\section{Direct citations from students opinions towards English lesson are presented below:}

MS1 "When I do my homework, It is very enjoyable and I like it, but when don't do my homework, I don't want to join the lesson."

MS2 "I used to like English lesson, but I don't anymore, because I don not understand anything due to the teacher."

MS3 "Due to the excessive homeworks, we can't study for the lessonand thus we fail."

MS4 "Rather than six hours a week, English lesson should be two hours a week. Because Englisg lesson is hard and it is not easy to understand."

MS5 "During all my school life, I have never liked English lesson, because English teachers are always boring." 
Mapping English teachers' favorable and unfavorable behaviors as voiced by high school students

MS6 "I think there is no need for English lesson, because we do not use it in Turkiye."

MS7 "I like English lesson very much, because we study it every year, so it is easy. Interesting words, interesting dialogues."

MS8 "I study English as if I would live in England for the rest of my life! I do not understand this lesson."

MS9 "English lesson is very boring because the English teacher doesn't teach well."

MS10 “A hard, boring and not interesting lesson, I don' like this lesson because I always get low marks."

MS11 "I like English lesson very much because I am interested in foreign languages. Also, I like the teacher so I am very interested in it."

MS12 "If the teacher tries to teach properly and in an entertaining way so do I try to learn more. However, as teachers are boring most of the time, so is the lesson."

FS1 "As long as it is not boring, I think it is a good lesson. And in fact it is up to the teacher."

FS2 "Englih lesson is a useless lesson because I do not understand and like it."

FS3 "English is good. It can be useful in future for master degree."

FS4 "English is a good lesson. We learn useful words."

FS5 "English lesson is like a wrapped candy. Good, Sweet and Protected."

FS6 "If the teaching of English goes on like this, learning English will never happen, because every year, the same subject are thought and speaking is never thought."

FS7 "English lesson take me to the other places. Once I speak English, I feel as if I were in England."

FS8 "Rather than grammar, a speaking based lesson should be thought. Because, in spite of so many years with grammar based-teaching, we can't speak."

FS9 "Though it has been lesson the which I have liked and enjoyed most, this year I don't want to go to school when we have English lesson." 


\section{Burhan ÜZÜM \& Ahmet ÇOBAN}

FS10 "English lesson should focus on communicative skills not on memorization."

FS11 "It should be on selectivity basis because there are people who don not like it."

FS12 "I don' like it because of English teacher."

Examining the negative opinions of the students towards English lesson, it can be said that they develop anxiety and dislike feelings towards English at a later stage of their life. According to MacIntyre and Gardner (1989), when students begin to learn a foreign language they do not feel any anxiety, but this anxiety results from the negative experiences they are exposed to later.

\section{DISCUSSION, CONCLUSION and RECOMMENDATIONS}

In this study, the purpose was to investigate favorable and unfavorable behaviors of English teachers from high school students' point of view, and their opinions about English lesson. According to the findings obtained in this study, it was determined that the most important behaviors students considered as favorable in English teachers were being concerned, sensitive and tolerant. Mehdipour and Balaramulu (2013, p. 3) found similar results in their studies that $93 \%$ of the students in their study with 900 university students expressed that the teachers were friendly and tolerant. Moreover, the students who expressed the understanding and tolerance of the English teachers were found to be similar to the ones obtained in the study of Tuncel and Balc1 (2015, p. 91). The researchers found that the number of students who said their teachers were mostly tolerant in their work was 23 . However, contrary to the findings in the present study, in the study titled "Communication Forms of Instructors According to Student Perceptions" by Ergin and Geçer $(1999$, p. 8), the items least marked by students were "Our instructors communicate with students on an equal basis" and "Our instructors put themselves into our shoes when necessary".

Among the results obtained in the present study were that English teachers teach well and they offer lots of activities. Likewise, in her study "A Research On Teachers' Behaviour Within Class", Senemoğlu (1987, pp. 50-57) found teachers' use of a variety of methods and techniques as $2,9 \%$ and their mastery over the subjects as $3,4 \%$.

Another result of this study was that English teachers are humorous, gentle and fair. In her study, Senemoğlu (2001, p. 15) also found that of 413 student 
Mapping English teachers' favorable and unfavorable behaviors as voiced by high school students

opinions, 48 opinions were about cheerful and humorous approaches of the teacher, 30 opinions about their being fair.

According to the expressions of high school students, despite all the negativity, the result was that English teachers struggle to teach them something. This is thought to be a motivating influence on the students. Because a diligent and hard-working teacher is always an examplary figure for his / her student. As a matter of fact, Gorham and Christopel (1992, p. 245) found in their study that the enthusiastic and diligent nature of teachers is a motivating factor for students. Of the 308 students surveyed, 186 expressed their opinions in this way.

In the present study, it was found that English teachers encouraged the students, even low in rate, they were prepared for the lesson. It can be said that the English teachers with these characteristics have a high proficiency level, they love their profession and they know the importance of their profession. Otherwise, as Sünbül (1996, p. 602) stated, teachers with low self-efficacy can not motivate their students and according to Atıc1 (2014, p. 423) those teachers who come to class unprepared and discriminate between their students can cause undesired behaviors in the classroom. In another study, Mehdipour and Balaramulu (2013, p. 3) investigated that teachers encouraged their students by applying different techniques. Moreover, in the study, Şahin (2011, p. 147) determined that according to the teacher perceptions among the professional qualifications required for an efficient teacher, coming to classroom planned and prepared ranked first with a rate of $27,8 \%$.

High school students in the present study stated that English teachers helped them with various matters such as facilitating marks on the exams. English teachers are supposed to do this in order to motivate students and prevent them from developing negative attitudes towards English lesson. A helpful teacher is thought to have important effect on students. In her study, Vural (2007, p. 52) discovered that $98,5 \%$ of the students regarded teachers' being helpful and supportive as motivation increasing factors.

In the present study, one of the results was that English teachers' teaching in English and their on time attendance to the classroom were considered as favorable behaviors. This can be attributed to the fact that students were aware of the importance of English and that the teacher took the lesson seriously.

According to the findings obtained in this study, the most prominent and apparent unfavorable behaviors of English teachers were being harsh, indifferent and not being able to teach English effectively. Similar findings can be seen in the study carried out by Atıcı and Çekici $(2009$, p. 514). They found that to the 


\section{Burhan ÜZÜM \& Ahmet ÇOBAN}

students, shouting (18) and getting angry (12) were among the negative methods teachers used. In his study "Teachers Attitudes and Their Reflections", Yapic1 (2007, p. 10) also stated that authoritarian teachers were distant in their relations with students and thus were indiferrent, and sometimes even harsh to them. Accordingly, Şahin (2011, p. 245) determined that according to the teachers' perceptions, among the characteristics a teacher should have with a $41 \%$ rate was to be able to convey what he knows to his students.

In this study, English teachers turned out to be discriminatory by ignoring those who didn't like English lesson, discriminating between male and female students, allowing certain students to speak more than others, showing different behaviours towards those good at English and bad at it. Those findings parallelled with the results in the study by Mehdipour and Balaramulu (2013, p. 3). In their study, the researchers established that $50 \%$ of students expressed that their teachers were nicer towrads certain students. For an effective and efficient teaching, without discriminating between students and by taking individual differences into account, it is necessary for a teacher to arrange the learning environment in a way to include all students in the process. Pointing out the necessary features of today's teacher, Oktay's (1991) statement about the importance of being objective and fair shows how much attention shoul be paid to this issue (as cited in Bozdoğan, Aydın and Yıldırım, 2007, p.86).

It can be deduced that in this study English teachers gave too much assignments, constantly dictated writing, taught just grammar and asked difficult questions in examinations, did not consider students' interests and needs, and not sufficiently and equally focus on speaking, listening, reading and writing-four basic aspects of a language. In line with the findings obtained in this study, students in the study of Tuncel and Balc1 (2015, pp.81-87) pointed out that their teachers did not teach in the way that would appeal to their interests and needs. Also, in their study Gorham and Christopel (1992, pp. 246-247) found out that 137 students out of 308 felt demotivated as a result of excessive homework. Besides, the results Liou (2009, p.147) obtained in his study are in line with the ones in this study. The researcher discovered that $98 \%$ of the students expressed that teachers focus more on pronounciation. In other words, the majority of the students' emphasis on the significance of the pronounciation revealled the necessity of not dwelling on grammar too much.

One of the results obtained as consequence of findings was such violent acts from English teachers towards students as throwing chalks, beating etc. Bulut (2008, p. 114) figured out similar results in his study. The researcher pointed out that teachers committed violence towards students mostly during the lesson, and 
Mapping English teachers' favorable and unfavorable behaviors as voiced by high school students

when cannot do this, they send students to the headmaster or deputy principal's office with serious accusitions. In this study, it was also concluded that English teachers pottered reading book, playing with cell phone, paying too much attention to their clothes, wearing perfume. This can be linked with teachers' having negative attitudes towards and not caring for their job.

Another result of this study was English teachers' humiliation of students through severe criticism, jokes, kidding, nicknaming and demoralization. Similarly, Kumral (2009, p. 99) found out in his study that 17 students stated that instructors had problems in their relation with students and disdained them. With a rate of 3,9 among the necessary traits a teacher should have according to teacher perceptions, Sahin (2011, p.253) investigated that a teacher should not disdain or make fun of his students.

It was also determined in this study that English teachers put pressure on their students by threatening them with low marks and reporting them to their parents. According to the students' opinions, English teachers constantly took students' point off on the exams, intented to give minuses to students who make mistakes during the class period, gave low marks to students' projects. In the teaching-learning process, all these practices both spoil class atmosphere and lead students to develop negative opinions towards the lesson. In another study, Tuncel and Balc1 (2015, p.9) determined that teachers threatened students either with low marks (5) or sending them in front of the discipline committee (8). However, as Deniz, Avsaroğlu and Fidan (2006, p.64) stated, a positive class atmosphere the teacher creates, allows students to develop positive opinions towards the lesson and increases their motivation.

One of the results of this study was English teachers' inefficiency in classroom management. This can be associated with their low self-efficacy beliefs or overcrowdedness of classrooms. In their study, Demirtaş, Cömert and Özer (2011, p.105) investigated that prospective teachers studying at department of English teaching had low self-efficacy. On the other hand, the results in this study that English teachers were boring and taught in an unexciting way paralleled with the findings in the studies by Ergin and Geçer (1999, p.10), Saylan and Yurdakul (1999 as cited in Ergin and Geçer, 1999, p.10). It was deduced from the study by Ergin and Gecer (1999) that the least item which students marked on the instructor evaluation inventory was the item "Our instructors present the topics in an interesting way". Saylan and Yurdakul (1999 as cited in Ergin and Geçer, 1999, p.10) determined in their study that $46 \%$ of the students stated that English teachers failed in teaching in an exciting way. This is thought to be due to the fact that teachers do not use foreign language teaching techniques 


\section{Burhan ÜZÜM \& Ahmet ÇOBAN}

and methods satisfactorily and efficiently. Koutrouba (2013, p. 9) also found out in her study that students expressed boring lesson as the reason with a rate of 10,7 $\%$ for their misconducts in the class. Misconducts can result from students' getting bored in the lesson. As a matter of fact, in his study, Sarıtaş (2006, p.183) discovered that the teachers who had clasrroom management lesson resorted to strategies including punishment and authority more often.

According to the opinions of the students, the late arrival or the early arrival of the teachers to lessons were among the unfavorable behaviors. Though low in the rate of expression, English teachers' not knowing the name of the students and constantly confusing them with each other were stated as unfavorable behaviors. This is thought to be due to the fact that the physical infrastructure of schools in our country's education system is not at the desired level. In other words, since the number of the students per class is very high, it makes it difficult for teachers to remember students' names and personal information about them. Neverthless, as Ercan (1997, p. 24), for an efficient, productive and successful learning, and for students to feel worthy, it is important for a teacher to know the students.

In the light of the data obtained in the study, it can be assumed that English teachers have professional knowledge by presenting activities, speaking Turkish during the class and delivering the lesson in English, and professional skills by teaching well, beng fair, encouraging, having good classroom management, coming to class prepared and teaching grammar, and that they have attitudes and values towards their proffesion by being caring/understanding/tolerant, cheerful/loving, diligent/endeavouring and helpful. This data demonstrate that they have such competencies stated in the General Competencies in Teaching Profession by the MoNE (2017) as being able to use different strategies, methods and techniques, taking into account individual characteristics of students, coping with undesirable behavior and stituations in class, being empathic and tolerant and valuing studets. The findings of Al-Mohaimeed and Khan (2014, p.185) in their study can be said to support the findings of this study. Researchers have found in their study on the students' perceptions about the qualities of the effective teachers that among the qualities expressed by students were understanding students, being sensitive to the needs and interests of the students, making jokes, being helpful, and not being prejudiced. Likewise, in his study " Effective Teacher's Attitudes According to Teacher's Perceptions", Şahin (2011, p. 245-248) found that teachers' qualifications such as coming to school in a planned and prepared way, providing classroom discipline and order, entering classroom in time were among the qualifications of teacher. The fact that having English proficiency, being able to implement English teaching principles, 
Mapping English teachers' favorable and unfavorable behaviors as voiced by high school students

managing classroom and personal characteristics were aming the qualities of English teachers in Nghia's study $(2015$, p. 14) can be said to be paralled with the findings of the present study.

As a result of the distribution of the unfavorable behaviors of the English teachers in terms of the teaching profession competence areas, it was revealed that the competence field, which had the most unfavorable behaviors, was the attitude and value competence area. In other words, it was concluded that the unfavorable behaviors English teachers should not have mostly accumulated in the attitude and value competence area. Bearing in mind these data, it can be stated that English teachers do not have such qualifications mentioned stated in the General Competencies in Teaching Profession by MoNE (2017) as demonstrating supportive attitudes to support students development and having good rapport with them adequately. As a matter of fact, the findings of Mezrigui (2015, pp.570-575) can be said to support the findings obtained in present study. The researcher observed that the teachers expressed the undesirable aspects of the affective roles such as disinterestedness, not calling the students with their names, being irrelevant, harsh, making fun of the students, discrimination. Similarly, in their study, Maden, Durukan and Aslan (2010, p.1374) determined that among the teachers's qualities having very low or negative effects were discrimination among students, nicknameing students, and applying brute force against students.

On the other hand, it was observed that other unfavorable behaviors expressed in the present study were frequently related to the field of professional skills competence area. In other words, according to the students' views, it appeared that English teachers cannot teach well, constantly give low marks, are boring, prepare hard exams for students, resort to brute force and cannot manage the class. From this point of view, it can be said that English teachers have some deficiencies in terms of professional skills. Similarly, Mezrigui (2015, p.571) observed features such as not being able to control the class, giving low grades, difficulty in examinations among the undesirable behaviors of the teachers' academic roles. Also, Qureshi et al. (2015, p.66) emphasized the importance of instructing and directing the class so that the teacher would prevent students from being bored while the course was being taught as excellent teacher characteristics. Even Raufelder et al. (2016, p. 38) determined not being able teach effectively as one of the poor qualities of teachers in their study.

The other three unfavorable behaviors expressed in the present study were in the area of professional knowledge competence. Accordingly, Ida (2017, p.144) concluded that giving excessive homework was the least important aspect of being a good teacher. MoNE (2018) underlines that the four basic skills in the 


\section{Burhan ÜZÜM \& Ahmet ÇOBAN}

secondary English Language Teaching Program must be integrated in a communicative way. The fact that English teachers do not speak English in the class and lead a grammar-based teaching points out that they both overlook the communicative aspect of the language and resort to outdated teaching approaches in English.

It was concluded that the frequencies of the favorable behaviors stated by female and male students were close to each other except for the caring/understand/tolerant, cheerful/loving, fair and encouraging behaviors. On the other hand, of the 19 unfavorable behaviors, the frequencies in terms of gender were close while there were obvious differences in terms of gender in the remaining 9 unfavorable behaviors.

\section{In the light of the findings of the study, the following recommendation can be given:}

1.Considering one of the most important results in the present study that English teachers are harsh and indifferent to students, effective communication programs either via in-service training courses or seminars can be arranged for English teachers to better understand and approach students.

2.English teachers should keep in mind that a language is not merely consisted of grammar and thus should not overlook the aspects in laguage such as speaking, listening, reading and writing. As a result, it can be recommended that students at English teaching department in universities can be instructed more heavily about the foreign language teaching techniques and methods, and more lessons relate to this issue can be added to the curriculums.

3. Teachers who are currently in charge can be trained on special teaching methods and techniques through seminars and courses.

4. English teachers should attend the lesson on time, not discriminate between students and be diligent in attending the class on time.

5. Keeping in mind the findings of the present study in which the posivitive and negative opinions of students toward English lesson were close, English teachers should motivate students to increase the positive opnions and use different techniques and methods to make students like English lesson. 
Mapping English teachers' favorable and unfavorable behaviors as voiced by high school students

\section{REFERENCES}

Ahmad, A., \& Sahak, R. (2009). Teacher-student attachment and teachers' attitudes towards work. Jurnal Pendidik dan Pendidikan, 24(55-72). https://core.ac.uk/download/pdf/83543406.pdf

Al-Mohaimeed, A. A., \& Khan, N. Z. (2014). Perceptions of Saudi medical students on the qualities of effective teachers. A cross sectional study. Saudi Medical Journal, 35(2), 183-188. https://www.ncbi.nlm.nih. gov/pubmed/24562519

Altınel, Z. (2006). Öğretmenlerin ve Öğrencilerin Bakış Açılarından, İngilizce Yabancı Dil Sinıflarında Öğrenci İstenmeyen Davranışları [Student misbehaviour in EFL classes: Teachers' and students' perspectives]. (Yüksek Lisans Tezi)[Master Thesis]. Çukurova Üniversitesi.

Atıcı, R. (2014). Sınıf içerisinde öğrencilerin davranışlarına etki eden etmenler [Student attitudes in class factors affecting]. The Journal of Academic Social Science Studies. II (28). 413-427. doi:http://dx.doi.org/ 10.9761/JASSS2445

Atıcı, M., \& Çekici, F. (2009). Ortaöğretimdeki öğretmen ve öğrencilerin istenmeyen davranışlarla baş etme konusundaki görüşlerinin karşılaştırılması [Comparison of Teachers and Students' Ideas about Dealing with Misbehaviour in Secondary Schools]. Kuram ve Uygulamada Ĕ̈itim Yönetimi, 15(60), 495-522. https://dergipark.org.tr/download/ article-file/108247

Aydın, S. \& Zengin, B. (2008). Yabancı dil öğretiminde kaygi: bir literatür özeti. Journal of Language and Linguistic Studies, 4(1) 81-94. https://www.jlls.org/index.php/jlls/article/view/58/58

Balay, R. \& Sağlam, M. (2008). Sınıf içi olumsuz davranışlara ilişkin öğretmen görüşleri [The opinions of teachers concerning the negative behaviors in class]. Yüzüncü Yll Üniversitesi Eğitim Fakültesi Dergisi, 5(2), 1-24. http://efdergi.yyu.edu.tr/uploads/r_balay-1542112905.pdf

Batumlu, D.Z. \& Erden, M. (2007). Yıldız Teknik Üniversitesi Yabancı Diller Yüksek Okulu Hazırlık Öğrencilerinin Yabancı Dil Kaygıları ile İngilizce Başarıları Arasındaki İlişki [The relationship between foreign language anxiety and English achievement of Yildız Technical Unıversity School of Foreign Languages preparatory students]. Çanakkale On Sekiz Mart 
Üniversitesi Eğitimde Kuram ve Uygulama, 3(1), 24-28. https://dergipark.org.tr/download/article-file/63258

Bozdoğan, A.E., Aydın, D. \& Yıldırım, K. (2007). Öğretmen adaylarının öğretmenlik mesleğine ilişkin tutumları [Attitudes of teacher candidates towards teaching profession]. Ahi Evran Üniversitesi Kırşehir Eğitim Fakültesi Dergisi, 8(2), 83-97. http://kefad.ahievran.edu.tr/Kefad/ ArchiveIssues/PDF/0d0631dc-8455-e711-80ef-00224d68272d

Bulut, İ. (2009). Öğretmen Adaylarının Öğretmenlik Mesleğine İlişkin Tutumlarının Değerlendirilmesi (Dicle ve Fırat Üniversitesi Örneği) [Evaluation of Teacher Candidates' Attitudes Concerning Teaching Profession (Dicle and Firat University Sample)]. Dicle Üniversitesi Ziya Gökalp Eğitim Fakültesi Dergisi, 14, 13-24. http://zgefdergi.com/ Makaleler/1052267735_14_02_Bulut.pdf

Bulut, S. (2008). Öğretmenden öğrenciye yönelik olan fiziksel şiddet: nicel bir araştırma [Violence that emerges from teachers toward students: a quantitative investigation]. Abant İzzet Baysal Üniversitesi Eğitim Fakültesi Dergisi. 8(1), 105-118. http://dergipark.ulakbim.gov.tr/aibuefd/ article/view/5000091359

Büyüköztürk, Ş., Kı1ıç, A. G. E., Karadeniz, Ö. G. Ş., \& Karataş, Ö. G. S. (2004). Sınıf içi öğretmen davranışları ölçeğinin geliştirilmesi: geçerlik ve güvenirlik analizleri [Development teacher behaviors within classroom scale: Validity and Reliability analysis]. Kuram ve Uygulamada Eğitim Yönetimi, 38(38), 212-239. http://Mutercim/Downloads/413-791-1-SM. pdf

Büyüköztürk, Ş., Çakmak, E.K., Akgün, Ö.E., Karadeniz, Ş., ve Demirel, F. (2016). Bilimsel Araştırma Yöntemleri (20. Bs.). Pegem Akademi

Büyükkaragöz, S. \& Kesici, Ş. (1996). Öğretmenlerin hoşgörü ve demokratik tutumları. Ĕ̈itim Yönetimi, 2(3), 353-365. http://Mutercim/Downloads/ 724-1387-1-SM.pdf

Creswell, J.W. (2016). Nitel Araştırma Yöntemleri: Beş Yaklaşıma Göre Nitel Araştırma ve Araştırma Deseni. (Çev.: Mesut Bütün ve Selçuk Beşir Demir). Siyasal Kitab Evi.

Çapa, Y. \& Çil, N. (2000). Öğretmen adaylarının öğretmenlik mesleğine yönelik tutumlarının farklı değişkenler açısından incelenmesi. Hacettepe Üniversitesi Eğitim Fakültesi Dergisi, 18(18), 69-73. http://www.efdergi. hacettepe.edu.tr/yonetim/icerik/makaleler/1063-published.pdf 
Mapping English teachers' favorable and unfavorable behaviors as voiced by high school students

Çelebi, S. (2009). İngilizce Dersine Yönelik Tutum ve Kaygılara İlişkin Öğrenci ve Ögretmen Görüslerinin Incelenmesi [Teachers and Students' Views on Anxiety in English Classrooms and Attitudes Towards]. Yüksek lisans tezi, Çukurova Üniveristesi.

Demirtaş, H., Cömert, M. \& Özer, N (2011). Öğretmen Adaylarının Özyeterlik İnançlarının ve Öğretmenlik Mesleğini İlişkin Tutumları [Pre-Service Teachers' Self-Efficacy Beliefs and Attitudes towards Profession]. Eğitim ve Bilim, 36 (159), 96-111. http://Mutercim/Downloads/278-8419-2PB.pdf

Deniz, M., Avşaroğlu, S. \& Fidan, Ö. (2006). İngilizce Öğretmenlerinin Öğrencileri Motive Etme Düzeylerinin İncelenmesi [An investigation of the levels of English teachers' motivating the students]. Inönü Üniversitesi Eğitim Fakültesi Dergisi, 7(11).61-73. https://www.pegem.net/dosyalar/ dokuman/11681deniz.pdf

Ercan, A.R. (1997). Öğrenmeyi Etkinleştiren ve Başartyı Yükselten Öğretmen Davranışları. Tekışık yayıncılık

Ergin, A. \& Geçer, A. (1999). Öğrenci algılarına göre öğretim elemanlarının iletişim biçimleri.[The perceptions of student regarding communication styles of faculty]. Ankara Üniversitesi Eğitim Bilimleri Fakültesi Dergisi, 32(1), 1-28. http://dergiler.ankara.edu.tr/dergiler/40/127/860.pdf

Ergun, M., \& Duman, T. (2000). Kritik durumlarda ogretmen davranislariII. Milli Egitim, 145. http://dhgm.meb.gov.tr/yayimlar/dergiler/Milli_ Egitim_Dergisi/145/ergun.htm

Ergür, D. O. (2004). Yabancı dil öğrenimi sürecinde kayg1 [Anxiety in foregn language learnig]. Hacettepe Üniversitesi Eğitim Fakültesi Dergisi, 26(26), 48-53. http://dergipark.ulakbim.gov.tr/hunefd/article/ view/5000048694/5000046014

Ertürk, S. (2013). Eğitimde Program Geliştirme. Tarcan matbaacılık.

Geçer, A. \& Deryakulu, D. (2004). Öğretmen yakınlığının öğrencilerin başarıları, tutumları ve güdülenme düzeyleri üzerindeki etkisi [The effect of teacher immediacy on sudents' success attitude and motivation]. Kuram ve Uygulamada Eğitim Yönetimi, 40, 518-543. https://dergipark.org.tr/ download/article-file/108386 
Gorham, J. \& Christophel, D. M. (1992). Students' perceptions of teacher behaviors as motivating and demotivating factors in college classes. Communication Quarterly, 40(3), 239-252.

Gurbetoğlu, A. ve Tomakin, E. (2011). Sevilen ve sevilmeyen öğretmen davranışlarına ilişkin öğrenci görüşlerinin incelenmesi [An analysis of students' views of liked and disliked teacher behaviours]. Ahi Evran Üniversitesi Eğitim Fakültesi Dergisi, 12(1), 261-276. http://kefad.ahievran.edu.tr/Kefad/ArchiveIssues/PDF/6ffde6bf-5d53e711-80ef-00224d68272d

Güçlü, N. (2002). Sınıf yönetimi açısından etkili öğretmen davranışları. Milli Ĕgitim Dergisi, 155-156. https://dhgm.meb.gov.tr/yayimlar/dergiler/ Milli_Egitim_Dergisi/155-156/terzi.htm

Huan, V. S. L., Quek, G. C. L., Yeo, L. S., Ang, R. P., \& Chong, W. H. (2012). How teacher-student relationship influenced student attitude towards teachers and school. The Asia-Pacific Education Researcher 21(1), 151159. https://repository.nie.edu.sg/bitstream/10497/14285/1/TAPER-21-1151.pdf

Ida, Z. (2017). What Makes a Good Teacher?. Universal Journal of Educational Research, 5(1), 141-147. doi:10.13189/ujer.2017.050118 https://files.eric. ed.gov/fulltext/EJ1124615.pdf

Konur, B. \& Konur, K.B. (2014). Sinıf ortamında istenmeyen öğrenci davranışlarına karşı öğretmen davranışları [Teachers' strategies against undesired student behaviors in classroom environment]. Akademik Sosyal Araştırmalar Dergisi, 2(8), 219-232. doi: http://dx.doi.org/ 10.16992/ASOS.421 http://www.asosjournal.com/Makaleler/145902929 _421\%20BARBAROS\%20KONUR.pdf

Koutrouba, K. (2013). Student misbehaviour in secondary education: Greek teachers' views and attitudes. Educational Review, 65(1), 1-19. https://doi.org/10.1080/00131911.2011.628122

Kumral, O. (2009). Öğretmen adaylarının öğretim elemanlarının davranışlarına yönelik algıları [Prospective teachers' perceptions of instructors' behaviors]. Pamukkale Üniversitesi Eğitim Fakültesi Dergisi, 25(25), 92102. https://docplayer.biz.tr/18810047-Ogretmen-adaylarinin-ogretimelemanlarinin-davranislarina-yonelik-algilari.html 
Mapping English teachers' favorable and unfavorable behaviors as voiced by high school students

Lavrič, A. (2006). Teachers' reflections on their attitude toward students. In Proceedings of the 31st Annual ATEE Conference: Co-operative Partnerships in Teacher Education. http://www.pef.uni-lj.si/atee/ Sprinthall, NA \& Sprinthall, RC (1990). Educational psychology: A developmental approach.(5thed.). McGraw-Hill International Editions.

Liou, Y. S. (2009). Who wants EIL? Attitudes towards english as an international language: a comparative study of college teachers and students in the greater taipei area. College English: Issues and Trends 3, 133-157. https://pdfs.semanticscholar.org/2d69/d8917aceb4e185ce104e8bd80a9eb 11a238e.pdf

MacIntyre, P.D. \& Gardner, R. (1989). Anxiety and second language learning: Toward a theoretical clarification. Language Learning, 39, 251-275.

Maden, S., Durukan, E. \& Aslan, A. (2010). Türkçe öğretmeni adaylarının öğretmen niteliklerine yönelik görüşleri [Turkish teacher candidates views about teacher qualifications]. Turkish Studies International Periodical For the Languages, Literatureand History of Turkish or Turkic, 5(4), 13641378. http://acikerisim.giresun.edu.tr/xmlui/handle/123456789/312

Mehdipour, Y. \& Balaramulu, D. (2013). Students' attitude toward teacher's behavior in Hyderabad universities. International Journal of Scientific and Research Publications, 3(6), 1-5. http://www.ijsrp.org/research-paper0613.php?rp=P181274

Mezrigui, Y. (2016). The Qualities of a successful EFL Teacher in the Eyes of Learners. International Journal of Humanities and Cultural Studies (IJHCS) ISSN 2356-5926,2(3), 569-585. http://journals.euser.org/ files/articles/ejls_may_aug_17/Youssef.pdf.

MoNE (Ministry of National Education].(2018). Ortaöğretim İngilizce Dersi (9.10.11 ve 12.sınıf] öğretim programı [Secondary school (9.10.11 and 12 grade) English lesson Teaching curriculum]. http://mufredat.meb.gov.tr/ ProgramDetay.aspx?PID=342

MoNE [Ministry of National Education].(2017). Öğretmenlik mesleği genel yeterlikleri [General Competencies in Teaching Profession] http://oygm.meb.gov.tr/www/ogretmenlik-meslegi-genel-yeterlikleri/ icerik/39 
Nghia, T. L. H. (2015). Vietnamese students' perception of English teacher qualities: Implications for teacher professional development. International Journal of Academic Research in Education and Review, 3(1), 7-19. doi: 10.14662/IJARER2014.058, https://www.researchgate.net/publication/32 2714917

Öztürk, B., Koç, G., \& Şahin, F. T. (2002). Sınıf öğretmenlerinin yüksek ve düşük beklenti geliştirdikleri öğrencilere yönelik davranışlarının farklılaşma durumu [Behavioral differences of the classroom teachers about high and low expected students]. Eğitim Bilimleri ve Uygulama, 1, 161-181. http://www.ebuline.com/pdfs/2Sayi/2-2.pdf

Qureshi, M. A. et al. (2015). First Year Medical Student's Viewpoint Regarding Qualities of an Excellent Teacher. Pakistan Journal of Education, 32(2), 61-74. https://aiou.edu.pk/sab/pje/Pakistan\%20Journals/VOL-32,ISSUEII,\%202015/Artical_4.pdf

Raufelder, D., Nitsche, L., Breitmeyer, S., Keßler, S., Herrmann, E., \& Regner, N. (2016). Students" perception of "good" and "bad" teachers-Results of a qualitative thematic analysis with German adolescents. International Journal of Educational Research,75, 31-44. https://doi.org/10.1016/ j.ijer.2015.11.004

Reeves, J. R. (2006). Secondary teacher attitudes toward including Englishlanguage learners in mainstream classrooms. The Journal of Educational Research, 99(3), 131-143. https://digitalcommons.unl.edu/cgi/viewcont ent.cgi? article $=1115 \&$ context $=$ teachlearnfacpub

Sanford, J. P. \& Emmer, E.T. (1988). Understanding Classroom Management: An observation guide. Allyn and Bacon.

Sarıtaş, M. (2006). Öğretmen adaylarının değerlendirmelerine göre sınıfta istenmeyen öğrenci davranışlarını değiştirmek ve düzeltmek amacıyla yararlanılan stratejiler [The Strategies Used in Order to Change and Ameliorate the Students' Classroom Behaviors That are Considered Undesirable in the Evaluations of Teacher Trainees]. Uludağ Üniversitesi Ĕ̈itim Fakültesi Dergisi, 19(1). 167-187. http://www.acarindex. com/dosyalar/makale/acarindex-1423935613.pdf

Semerci, N. \& Semerci, Ç. (2004). Türkiye'de Öğretmenlik Tutumları [Attitudes towards teaching in Turkish]. Firat Üniversitesi Sosyal Bilimler Dergisi, 14(1), 137-146. http://web.firat.edu.tr/sosyalbil/dergi/arsiv/cilt14/sayi1/ 137-146.pdf 
Mapping English teachers' favorable and unfavorable behaviors as voiced by high school students

Senemoğlu, N. (1987). Sınıf içi öğretmen davranışları üzerine bir araştırma. Ĕ̈itim ve Bilim, 11(64), 50-57.

Senemoğlu, N. (2001). Öğrenci görüşlerine göre öğretmen yeterlilikleri. Eğitimde Yansımalar: VI. 2000 Yllında Türk Milli Ĕ̈itim Örgütü ve Yönetimi, 1113.

Sert, N. (2007). İngilizce eğitim programında sınıf disiplini [classroom discipline in elt curriculum]. Kuram ve Uygulamada Eğitim Yönetimi, 49(49), 93127. https://www.pegem.net/Akademi/3-2859-Ingilizce-Egitim-Program inda-Sinif-Disiplini.aspx

Siyez, D. M. (2009). Liselerde görev yapan öğretmenlerin istenmeyen öğrenci davranışlarına yönelik algıları ve tepkileri [High School Teachers' Perceptions of and Reactions towards the Unwanted Student Behaviors]. Pamukkale Üniversitesi Eğitim Fakültesi Dergisi, 25(25), 6780. http://pauegitimdergi.pau.edu.tr/Makaleler/334748244_Di\%C4\%9F dem\% 20M\%C3\%BCge\%20Siyez1.pdf

Smith, M. R. (2010). Teachers' Attitudes Towards English Language Learners in Rural Schools Implementing Sheltered English and English as a Second Language Compared to Teachers' Attitudes in Schools with No Clearly Defined Model of Language Services. Student Work. Paper 23. (Doctoral Dissertation). Faculty of the Graduate College at the University of Nebraska. https://digitalcommons.unomaha.edu/cgi/viewcontent.cgi? article $=1029 \&$ context $=$ studentwork

Sun, R. C., \& Shek, D. T. (2012). Student classroom misbehavior: an exploratory study based on teachers' perceptions. The Scientific World Journal. Article ID 208907. http://dx.doi.org/10.1100/2012/208907

Sünbül, A.M. (1996). Öğretmen niteliği ve öğretimdeki rolleri. Eğitimde Nitelik, 1, 597-607. http://www.kuey.net/index.php/kuey/article/view/748

Şahin, A. (2011). Öğretmen algılarına göre etkili öğretmen davranışları [Effective Teacher's Attitudes According to Teacher's Perceptions]. Ahi Evran Üniveristesi Eğitim Fakültesi Dergisi, 12(1), 239-259. http://kefad. ahievran.edu.tr/InstitutionArchiveFiles/f44778c7-ad4a-e711-80ef-00224d 68272d/d1a3a581-af4a-e711-80ef-00224d68272d/Cilt12Sayi1/JKEF_12 _1_2011_239_259.pdf 


\section{Burhan ÜZÜM \& Ahmet ÇOBAN}

Şahin, S., \& Arslan, M. C. (2014). Öğrenci ve öğretmen görüşlerine göre istenmeyen öğrenci davranışlarına karşı kullanılan öğretmen stratejilerinin ögrenciler üzerindeki etkileri [The effects of teacher strategies used against undesirable student behaviours on students according to student and teacher opinions]. Turkish Studies-International Periodical for the Languages, Literature and History of Turkish or Turkic, 1399-1415. http://www.turkishstudies.net/DergiTamDetay.aspx?ID=6103

Tuncel, G. \& Balcı, A. (2015). Demokratik toplumlarda öğretmen nitelikleri ve öğrencilere yansımaları [Attributes of teachers and their reflections on students in democratic societies]. Marmara Coğrafya Dergisi, 31, 82-97 https://dergipark.org.tr/download/article-file/3458

Walker, A., Shafer, J., \& Iiams, M. (2004). Not in my classroom": Teacher attitudes towards English language learners in the mainstream classroom. NABE Journal of Research and Practice,2(1), 130-160. http://citeseerx.ist.psu.edu/viewdoc/download?doi=10.1.1.579.2287\&rep $=$ rep1\&type $=$ pdf

Vural, S. (2007). Teachers' and Students' Perceptions of Teacher Motivational Behavior. Master thesis. Bilkent University.

Yapıc1, M. (2007). Öğretmen tutumları ve yansımalar. Bilim, Eğitim ve Düşünce Dergisi, 7(3).

Yıldırım, A. \& Şimşek, H. (2013). Sosyal Bilimlerde Nitel Araştırma Yöntemleri (9. bask1.). Seçkin yayınları. 